\title{
Symposium
}

\section{The fiscal crisis continues: From liberalization to consolidation}

\author{
Wolfgang Streeck \\ Max Planck Institute for the Study of Societies, Paulstrasse 3, 50676 Cologne, Germany. \\ E-mail: ws@mpifg.de
}

\begin{abstract}
The article discusses the impact of the financial crisis on the German political economy and the fiscal capacity of the German state. It argues that recent events have accelerated and reinforced the longer-term trends analysed in the book, "Re-forming Capitalism", rather than changing them.

Comparative European Politics (2010) 8, 505-514. doi:10.1057/cep.2010.16
\end{abstract}

Keywords: Financial crisis; fiscal crisis; liberalization; Germany

\section{Reply}

The merits and demerits of my book Re-Forming Capitalism may be judged by the curious and attentive reader, perhaps made more curious and attentive by the two reviews joined in the present symposium. I thought that I would best use the space allocated to me by the kindness of the editors to explore how the current German experience in the 'Great Recession' (Reinhart and Rogoff, 2009b) may be interpreted from the perspective I develop in my account of the liberalization of the German political economy since the watershed of the 1970s. Reading the international and, to an extent, the German press, one sometimes wonders whether the salad days of the Wirtschaftswunder have somehow come back. Unemployment is reported to have hardly increased, owing to labor market policy instruments such as short-time work that have once again become the envy of the world; public deficits have grown, but less so than elsewhere; public debt has made a great leap forward, but in the United States and the United Kingdom, not to mention Greece, the leap was far greater; ${ }^{1}$ and complaints are once more heard from neighboring countries about excessive German productivity and competitiveness, unreasonably reasonable trade unions, an all-too disciplined and stability-conscious citizenry, and rigid insistence on international agreements like the no-bailout 
clauses of the Monetary Union treaties that German meanness has apparently somehow inflicted on the country's unknowing European allies.

A central result of my investigation in the dynamics of the German political economy in the last third of the twentieth century is that one should not trust momentary snapshots, including cross-national snapshots comparing different countries at a given point in time. All social systems are always in motion, moving forward in history and changing in the process. Where they are going and how they will look in the future, one cannot exactly know; but it helps to remember their trajectory and be aware of the trends to which they were subject in their recent and not-so-recent past. Differences over time are more telling than differences between places. 'Liberal' and 'coordinated' variants of capitalism may be found in cross-sectional comparison to differ with respect to the extent to which they are driven by markets or political intervention; but what if they are also found to be undergoing parallel processes of liberalization, at similar speed and following the same logic (R-FC, Chapter 12)? ${ }^{2}$

The story told and analyzed in my book culminates in the Schröder years of German politics, especially the time of the second Schröder government (2002-2005) and the 'reforms' of Agenda 2010. This was as far as my data extended. At that point, the established 'German model' of state-sponsored social peace and social partnership was in ruins: with unions organizing less than 20 per cent of the workforce; long-term unemployment at a record high; collective bargaining in what used to be the public sector in shambles as a result, among other things, of privatization of public assets and services; worker coverage by collective agreements and works councils on a decade-long steady decline; poverty rates and the Gini coefficient of inequality rapidly rising up to the OECD average; ${ }^{3}$ one-third of the Federal budget spent on subsidizing a social security system utterly unable to subsist on the highest payroll taxes ever; and interest on the public debt having grown to a level where the new debt had to be spent entirely on servicing the old debt (on the latter see R-FC, Chapter 5).

Rather than embarking on fanciful projects like raising taxes on the rich, limiting the export of capital, encouraging unions to demand higher wages, lowering the pension age to 60 , introducing an unconditional basic income for all citizens and so on, the Red-Green government chose a policy of continued and accelerated liberalization. Not everything it did may have been without alternative, some things might have been done better, and others could perhaps have been done with a little more courage. What my book tries to explain is why what was done in the end followed the liberalization path on which the German so-called 'coordinated market economy' ${ }^{4}$ had been moving for at least two decades. I concluded, in short, that I was witnessing the climax of a long-drawn departure from a post-war political-economic order that had run out of steam, from a political peace formula that had lost its material 
foundation, and from a national compromise between capital and labor that had exhausted itself. A similar process had taken place in other capitalist countries. In Germany it had taken longer, as everything does, but now the hour of truth had arrived. Even Sweden in the 1990s cut taxes instead of raising them, privatized a good part of social security, accepted an unprecedented level of structural unemployment, essentially gave up on wage solidarity, and the like. Lacking any idea of how to shift from liberalization to a neo-social democratic trajectory, however that may have looked, the Schröder government, driven by an endemic fiscal crisis ${ }^{5}$ and following the model of 'New Labour', the advice of economists and the prescriptions peddled by international organizations like the OECD and the European Union, increased the pressure on the losers and the rewards for the winners, imposed higher insecurity on those in the middle, and generally did what it believed it could to bring back economic growth and regain at least some political capacity for the state that it was running.

As is well known, Schröder paid for his Agenda with his political life, and so did, almost, his party. The Grand Coalition government under Angela Merkel that took office in 2005 abstained from further attacks on the remnants of the 'German system' and instead chose to reap the fruits of the labors of its predecessor. Its main objective was budget consolidation. While Schröder's income tax cuts were left in place, consumption taxes were raised instead (Streeck, 2007). Apart from cosmetic surgery, the reform of unemployment insurance and labor market policy that had cost Schröder his office ('Hartz IV') was left untouched. Together with an unexpected economic upswing, this reduced the level of unemployment (in any case: of unemployment as measured under the reformed labor market regime) to a point where the almost automatic, secular increase in welfare state spending that had driven state finances into an endemic deficit (see R-FC, p. 69) could be temporarily arrested. Thus, in 2008, the share of the federal budget that was more or less available for discretionary spending was up at 22 per cent, compared to 19 per cent in 2005. (Of course in 1970, it had still been 40 per cent, from where it had declined more or less steadily over more than three decades; Streeck and Mertens 2010a, b).

Then came the 'financial crisis' of 2008, which was nothing else than a worldwide collapse of a regime of artificial prosperity built on public and private debt of such a magnitude that doubts on the ability of debtors to live up to their obligations were apt in principle to break out any time and bring the global economy to a standstill. In all advanced countries, the event had the paradoxical effect that for the moment it forced governments, or allowed them depending on one's perspective, to renounce fiscal consolidation and fight the collapse of trust in private debt being repaid by taking up more public debt, at a level unseen since the Second World War. While the crisis was deeply 
frightening to political leaders, the more so the more they learned about it, the unexpected license for the time being to refrain from further fiscal consolidation was far from unwelcome. In fact, one reason why 'Keynesianism' was so eagerly exhumed was obviously that it offered a respite, if only a shortlived one, from the political rigors of fiscal austerity. In Germany, the two parties in the federal government, Christian Democrats and Social Democrats, had been watching each other with rising suspicion for some time as the 2009 election came closer. ${ }^{6}$ The crisis and the need to fight it with fiscal expansion allowed both of them to dispose on very short order of their increasingly uncomfortable rhetoric of austerity and sustainability, and return to their customary toolkit of political clientelism and the courting of electoral favor by targeted public spending.

There can be no doubt that recourse to increased, and indeed vastly increased, public spending was both inevitable and effective as a way of stabilizing the capitalist global economy. This holds in particular for Germany. It is true that the government's response to the crisis wiped out whatever Schröder II and the Grand Coalition may have achieved in terms of fiscal consolidation. But these same achievements also provided a cushion that made the response to the crisis easier and less expensive than, perhaps, in other countries. For example, in 2009 the Federal Labor Agency could draw on a cash hoard of savings from unemployment benefit made possible by Hartz IV, to fund an unprecedented expansion of short-time work. It also helped, and still helps, that Germany has always been reluctant to follow received wisdom and accelerate the structural change of its economy from industry to services. Today, it is commonplace that a country that is able to sell sophisticated manufactures in international markets can afford to be more conservative with respect to fiscal stimulus, as it stands to benefit from fiscal stimulus applied by other countries. It also seems to be helpful that unlike the United States and the United Kingdom, but also Sweden, fiscal consolidation in Germany in the past decade was not accompanied by an expansion of private debt - what Colin Crouch has called 'privatised Keynesianism' (Crouch, 2009). Today, one recognizes that this has helped contain economic risk, and perhaps made private demand less inclined to implode in the course of the financial crisis.

Nevertheless, the Schröder moment is bound to return, and indeed very soon and almost certainly worse. That others are still envying 'the Germans' may be true, although some of the popular accounts of German economic performance may be overstated in the hope of extracting German subventions for countries that feel, rightly or wrongly, that they are suffering more. Moreover, belief in a new German miracle was undoubtedly encouraged by the self-congratulatory rhetoric of the 2009 German election campaign, with all parties avoiding as best they could to appear 'pessimistic', not least in order to make their 
promises of still more tax cuts and no new taxes appear a little more credible. Underlying the euphoria of the election campaign as well as of the subsequent formation of the second Merkel government - a coalition with the liberal Free Democrats - were fears of confusing an electorate that still remembered vividly stern governmental insistence on fiscal responsibility. Also contributing were more or less desperate hopes for economic growth after the crisis that were so unrealistic that they were only rarely made explicit. Of course nobody can with certainty predict future growth, and surprises seem always possible, like after 2005. But to be cautious it is not necessary to be convinced, as most economists tend to be, that high public debt will as such depress economic growth. ${ }^{7}$ It is enough to remember the long-term historical decline of growth rates since the 1970s, not to mention the highly skewed demographic composition of the German population, to discount the prospect of Germany happily growing out of its fiscal crisis in the coming decade. ${ }^{8}$

Fiscal consolidation, that is to say, will be back on the agenda, if only because the Grand Coalition in early 2009, in an attempt to legitimate fiscal expansion, passed a constitutional amendment obliging the federal government to balance its budget by 2016 (Streeck and Mertens, 2010b). Beginning in 2011, this means that year by year, about $€ 10$ billion have to be shaved off the deficit, either by cuts in expenditure or by increases in taxes. The immensity of this project is revealed if we take a longer view and notice that the crisis has no more than accelerated a firmly established, decade-old habit of the German political economy to generate public sector deficits almost every year, regardless of economic conditions and the parties in government (R-FC, p. 69). That trend would have to be broken, in circumstances more difficult than at any other time in the post-war period. As noted, in Germany the recent increase in public deficit was less than in the United States and the United Kingdom, and the accumulated public debt compared to GDP remains a lot lower than, say, in Italy or Japan. ${ }^{9}$ Still, it will shortly be 20 percentage points higher than before the crisis, and overall a lot higher than in a country like Sweden. Whatever this means, it should be clear that the happy years of fiscal stimulus in 2009 and 2010 cannot possibly have been more than a short break in a long period of austerity that began in the early 2000s at the latest and will last for many years to come (Streeck and Mertens, 2010b).

Another lesson I learned researching and writing my book is that one should, with John Maynard Keynes, be careful with predictions, and even more so if they are about the future. Nevertheless, we are very probably more than safe in assuming that the ambitious targets of the balanced budget amendment will not be reached; and if they will, then only by the government fiddling the accounts. This, however, does not mean that the new fiscal constitution of Germany will be without consequence. There are good reasons to believe that the conservative-liberal government will not be willing to risk 
losing the next federal election in retaliation for either cutting benefits or raising taxes, if only because this would enable a successor government, Red-Green or even Red-Red-Green, to return to interventionist spending. In fact, international comparison suggests that conservative parties are less interested in avoiding public deficits and high government debt than are Social-Democratic ones (Wagschal, 1996), on account of the latter's general preference for activist government, which requires a state with its fiscal capacities intact. However, this will by no means prevent a conservative government from enforcing a strict regime of austerity on public policy, under which any government activity, current or proposed, will be scrutinized in terms of a general imperative to bring down the deficit - a regime of austerity whose effectiveness could only be diminished if the deficit was actually to disappear. $^{10}$

That it will not in the German case, and that austerity will precisely for this reason remain the dominant prescription for public policy in the foreseeable future, is assured not just by the balanced budget amendment, the refusal of the present government to raise taxes, and growing tax resistance of voters that will not fail to impress even the hardiest Social Democrats. Austerity will also be reinforced by a built-in, quasi-automatic increase of spending on old-age pensions, owing to demographic change, and by the inevitable rise, not least in the course of the impending re-regulation of the banking industry, of interest rates on the, vastly increased, government debt. Neither of the two can be much affected by cost-saving policies: interest rates are dictated by financial markets while public pensions in Germany's pay-as-you-go system have already been cut to a point beyond which the system's legal base may begin to erode. As a result, it will be the ever smaller share of federal government spending that is not mandatory and could, in principle, be flexibly allocated to newly arising tasks and objectives that will have to bear the brunt of constitutionally prescribed budget consolidation. Prominent among these are general and vocational education, provision for families, measures to improve the opportunities of immigrants and the long-term unemployed and their children, the physical infrastructure, social services at the communal level and the like. They, above all, will be the targets of the long succession of budget cuts and fiscal emergency operations that will dominate the political agenda in the next decade and that will in effect make the German state's portfolio of public policies ever more inflexible and out-of-joint with changing social needs and problems.

A further lesson from the book seems applicable here. Social change, including important social change, sometimes proceeds so slowly and gradually as to be imperceptible in the short run (Streeck and Thelen, 2005). Twenty years is long in the life of an individual, including an individual social scientist, but it may not be much for a process of major social transformation. In cases

510 (C) 2010 Macmillan Publishers Ltd. 1472-4790 Comparative European Politics Vol. 8, 4, 505-514 
of this kind, it requires historical memory for the social scientist to see that something is going on, and what it is. That such memory takes time to build may be why social scientists tend to prefer static models of society over dynamic ones. Models of this sort, however, cannot notice whether what is observed at present as a condition is in fact a moment in an unfolding process of long duration, making it unlikely that it can be undone on short order. How deep and lasting, in other words, the fiscal crisis of the German state will be, once the financial crisis of the global economy will be over, we can assess only if we are aware of the dynamics of the German fiscal crisis before the financial crisis.

What, then, is likely to happen in and to the German political economy in coming years, provided the sky does not fall in over Europe, which it of course may? I vote for an accelerated but still gradual continuation of the liberalization process I have described in the book - a process of market expansion and commodification, probably following the two-steps-forwardone-step-back pattern characteristic of the Polanyian 'double movement' (Polanyi, 1957 [1944]), but overall unbroken, not least owing to the secular weakening of the governing capacity of the national state. ${ }^{11}$ Citizens will, as best they can, adjust to the new conditions, often in the belief that there is nothing really new about them, or that nothing can be done about them anyway. Those who can afford it will learn to procure more and more of the services they need from private markets rather than public institutions. Their exit from the public sector will be accompanied by declining interest in voice, and correspondingly less effective voice of those who still need a state. More private provision and less public participation will go together with increasing resistance to being taxed, especially if higher taxes would for a significant time have to be used to lower deficits and pay off old debt, as opposed to delivering more or better public goods. Private schools and universities will continue to proliferate, and so will private arrangements for social security and, increasingly, health care. Inequality and the social distance between milieus will grow further, reinforced by rising cultural heterogeneity causing, among other things, stiffer competition especially at the lower end of the labor market. Popular desire for more growth will justify stronger 'work incentives': higher private profits at the top of the social scale, lower public benefits at the bottom. Most people will have to work harder and for less. As there is a lot of 'fat' to cut, and change will be slow and perceptible only for those with a memory of the past, there may not be much protest, and continuously declining social provision may by and large be taken for granted.

Perhaps the landing of Germany in the new world of liberal post-welfare capitalism will be soft, as apparently it is in Sweden, or has been so far. Compared to other countries, Germany will very likely be a laggard rather 
than a leader, allowing for favorable or, as the case may be, invidious comparison, and indeed for denial of the descent from social democracy as such. Nevertheless, already now commentators in the 'varieties of capitalism' tradition observe the German political economy turning dualistic (Palier and Thelen, 2010), without being able to say why the ongoing division in a protected core and a precarious fringe should stop where it is now, and why the fringe should not continue to eat into the core until nothing much remains of it. $^{12}$ Of the now well-known types of gradual change (Streeck and Thelen, 2005), what we may increasingly recognize in Germany is liberalization through 'drift', caused largely by 'exhaustion' of fiscal capacities, combined with some 'layering' where dualism prevails. Hope for renewed growth will be urgently needed to keep the society quiet, and perhaps it will eventually be possible, like in the United States, to make it socially and culturally obligatory to have private 'dreams' of success and prosperity even in the midst of public decay. German, or Lutheran, Gemütlichkeit, or what is still left of it, is bound to disappear under the impact of advancing market pressures, together with the last traditionalist vestiges of protection from the stress of the neo-Calvinist rat race, in a new age of ever higher pressures for flexibility and performance (R-FC, Chapter 17). But in the eyes of many, including many Germans, and in particular of a new generation of competitive Leistungsträger, there is no respectable life outside of fierce competition, stoic acceptance of rising uncertainty, and shared entrepreneurial adventure anyway.

\section{About the Author}

Wolfgang Streeck is Director at the Max Planck Institute for the Study of Societies in Cologne, Germany. From 1988 to 1995, he was Professor of Sociology and Industrial Relations at the University of Wisconsin-Madison. He is Chief Editor of Socio-Economic Review. His latest publications include: Institutions in history. Bringing Capitalism Back In. In: Glenn Morgan et al, eds., The Oxford Handbook of Comparative Institutional Analysis, Oxford University Press, 2010, pp. 659-686; An Index of Fiscal Democracy (with Daniel Mertens). MPIfG Working Paper 10/3, Köln: Max-Planck-Institut für Gesellschaftsforschung, 2010; Flexible Employment, Flexible Families, and the Socialization of Reproduction. MPIfG Working Paper 09/13, Köln: Max-Planck-Institut für Gesellschaftsforschung, 2009.

\section{Notes}

1 By 2014, according to the Economist (27 March 2010, p. 23), public debt in the United Kingdom will amount to 98 per cent of GDP, as compared to 57 per cent in 2008 (an increase of 41

512 (C) 2010 Macmillan Publishers Ltd. 1472-4790 Comparative European Politics Vol. 8, 4, 505-514 
percentage points). The respective figures for the United States are 108 and 70, with an increase of 38. In Germany, public debt stands to rise by 20 percentage points, from 69 to 89 per cent.

2 R-FC refers to Re-Forming Capitalism (Streeck, 2009).

3 After the book had gone to print, the OECD published a remarkable study on the increase of inequality in OECD countries, under the title of Growing Unequal (OECD, 2008). Germany turns out to have been among the countries where inequality and poverty increased most in the period between 2000 and 2005. The study confirms the more scattered evidence on which I relied in the book (R-FC, pp. 41-43).

4 In the book, I take issue with this concept at great length (see in particular Chapter 11). This is why I use it only in quotation marks here.

5 I have analyzed the nature of that crisis before (Streeck, 2006, 2007). My chapter in the book edited by Miskimmon et al is a shorter version of Streeck (2007), which is available on the internet: http://www.mpifg.de/pu/mpifg_dp/dp07-7.pdf.

6 On the following, see Streeck and Mertens (2010b).

7 See Reinhart and Rogoff (2009a), who claim to have found that countries with a public debt of more than 90 per cent of GDP are unable on their own to restore significant growth.

8 In the decade before 2006, average real growth of the German economy was 1.3 per cent a year.

9 In Italy public debt amounted to 114 per cent of GDP in 2008 and is predicted to rise to 129 per cent in 2014. The respective figures for Japan are 172 per cent and 246 per cent.

10 For a brilliant early analysis of the left-right dimension of budget deficits, and the vexing problems it raises for the Left, see Pierson (1998, 2001).

11 On the following, see Streeck (2006).

12 Older analyses of dualism describe the presence of a secondary, or marginal, sector as stabilizing the primary, or core, sector (see Piore in Berger and Piore, 1980). Such functionalism is absent in current usage of the concept, suggesting that dualism as observed today may be no more than a transitory condition on the way to a generally more 'flexible', liberal regime.

\section{References}

Berger, S. and Piore, M. (1980) Dualism and Discontinuity in Industrial Societies. Cambridge, MA: Cambridge University Press.

Crouch, C. (2009) Privatised Keynesianism: An unacknowledged policy regime. British Journal of Politics and International Relations 11(3): 382-399.

OECD. (2008) Growing Unequal: Income Distribution and Poverty in OECD Countries. Paris: Organisation for Economic Cooperation and Development.

Palier, B. and Thelen, K. (2010) Institutionalizing dualism: Complementarities and change in France and Germany. Politics and Society 38(1): 119-148.

Pierson, P. (1998) The deficit and the politics of domestic reform. In: M. Weir (ed.) The Social Divide: Political Parties and the Future of Activist Government. Washington DC; New York: Brookings Institution Press and Russell Sage Foundation, pp. 126-178.

Pierson, P. (2001) From expansion to austerity: The new politics of taxing and spending. In: M.A. Levin, M.K. Landy and M.M. Shapiro (eds.) Seeking the Center: Politics and Policymaking at the New Century. Washington DC: Georgetown University Press, pp. 54-80.

Polanyi, K. (1957 [1944]) The Great Transformation: The Political and Economic Origins of Our Time. Boston, MA: Beacon Press.

Reinhart, C.M. and Rogoff, K.S. (2009a) Growth in a time of debt. Unpublished manuscript.

Reinhart, C.M. and Rogoff, K.S. (2009b) This Time is Different: Eight Centuries of Financial Folly. Princeton, NJ: Princeton University Press. 
Streeck, W. (2006) A state of exhaustion: A comment on the German election of 18 September. The Political Quarterly 77(1): 79-88.

Streeck, W. (2007) Endgame? The Fiscal Crisis of the German State. Cologne, Germany: Max Planck Institute for the Study of Societies. MPIfG Discussion Paper 07/7.

Streeck, W. (2009) Re-forming Capitalism: Institutional Change in the German Political Economy. Oxford: Oxford University Press.

Streeck, W. and Mertens, D. (2010a) An Index of Fiscal Democracy. Cologne, Germany: Max Planck Institute for the Study of Societies. MPIfG Working Paper 10/3.

Streeck, W. and Mertens, D. (2010b) Politik im Defizit: Austerität als fiskalpolitisches Regime. Cologne, Germany: Max Planck Institute for the Study of Societies. MPIfG Discussion Paper $10 / 5$.

Streeck, W. and Thelen, K. (2005) Introduction: Institutional change in advanced political economies. In: W. Streeck and K. Thelen (eds.) Beyond Continuity: Institutional Change in Advanced Political Economies. Oxford: Oxford University Press, pp. 1-39.

Wagschal, U. (1996) Staatsverschuldung: Ursachen im internationalen Vergleich. Opladen, Germany: Leske + Budrich. 